\title{
HitLER'S PROFESSORS
}


This page intentionally left blank 


\title{
Hitler's PROFESSORS
}

\author{
The Part of Scholarship \\ in Germany's Crimes Against \\ the Jewish People
}

Max Weinreich

Yalè University Press

New Haven and London 
Originally published in 1946 by the Yiddish Scientific Institute-YIVO-as part of the YTVO English Translation Series. Published in 1999 with a new Foreword by Yale University Press.

Copyright (ㅇ 1999 by YIVO Institute for Jewish Research.

All rights reserved.

This book may not be reproduced, in whole or in part, including illustrations, in any form (beyond that copying permitted by Sections 107 and 108 of the U.S. Copyright Law and except by reviewers for the public press), without written permission from the publishers.

Printed in the United States of America.

\section{Library of Congress Cataloging-in-Publication Data}

Weinreich, Max, 1894-1969.

[Hitlers profesorn. English]

Hitler's professors : the part of scholarship in Germany's crimes against the Jewish people / Max Weinreich.

p. $\mathrm{cm}$.

Originally published: New York : Yiddish Scientific Institute-YIVO, 1946.

With new introd.

Includes bibliographical references and indexes.

ISBN 978-0-300-05387-6 (alk. paper)

1. Antisemitism-Germany. 2. Learning and scholarship-Germany-History-20th century. 3. Germany-History-20th century. 4. Germany-Intellectual life. 5. Holocaust, Jewish (1939-1945)-Causes. I. Title.

DS146.G4W3913 1999

$943.086-\mathrm{dc} 21$

$98-48936$

CIP

A catalogue record for this book is available from the British Library.

The paper in this book meets the guidelines for permanence and durability of the Committee on Production Guidelines for Book Longevity of the Council on Library Resources. 